\title{
Gempa Bumi : Hubungan Data Sensor MAG3110 dengan Data Sensor ADXL345 Berbasis IoT
}

\author{
Dodi Yudo Setyawan*1,Nurfiana ${ }^{2}$, Lia Rosmalia $^{3}$, Melia Gripin Setiawati ${ }^{4}$ \\ 1,2,3,4 Sistem Komputer Institute Informatics and Business Darmajaya Z.A Pagar Alam Street No. 93 Gedong \\ Meneng, Bandar Lampung, Telp/fax $0721787214 / 0721700261 *$ e-mail: \\ dodi@darmajaya.ac.id',nurfiana@darmajaya.ac.id ${ }^{2}$,liarosmalia@darmajaya.ac.id ${ }^{3}$, \\ melia.gripin@darmajaya.ac.id ${ }^{4}$
}

Diterima (06 Mei 2021), Direvisi (30 Juli 2021)

\begin{abstract}
The earthquake early warning system was built by implementing the IoT-based telemetry method to measure the earth's magnetic flux and vibrations at the latitude coordinates and longitude coordinates (5.640274, 104.3050093), (-5.600941, 104.7788183) through the MAG3110 and ADXL345 sensors that were integrated in the raspberry pi3 as a server and applications on Android phones used for measurement data display. The result of the measurement data was that the average impact of the arising earth anomaly and vibration at the same coordinates took 400 seconds in the anomaly range of $395 \mu T$ to $404 \mu T$. The conclusion of this study was that the study was able to be used as a basic to design the real-time earthquake warning system.
\end{abstract}

Keywords: Earthquake, IoT, Telemetry.

Abstrak. Untuk membangun sistem peringantan dini gempa bumi kami menerapkan metode telemetri berbasis IoT untuk mengukur flux magnet bumi dan getaran pada koordinat lintang dan bujur bumi (5.640274, 104.3050093) dan (-5.600941, 104.7788183) menggunakan sensor MAG3110 dan ADXL345 yang diintegrasikan dalam raspberry pi3 sebagai server dan aplikasi di handphone android digunakan untuk menampikan data pengukuran. Hasil pengukuran yang diperoleh rata-rata dampak yang ditumbulkan dari timbulnya anomali dengan datangnya getaran pada koordinat yang sama membutuhkan waktu 400 detik dari rentang anomali sebesar $395 \mu \mathrm{T}$ sampai dengan $404 \mu \mathrm{T}$. Hal ini menurut peneliti dapat dijadikan dasar untuk membangun sistem peringatan gempa bumi secara real time.

Keywords: gempa bumi, IoT, Telemetri

\section{PENDAHULUAN}

Peristiwa gempa bumi pasti terjadi baik dalam skala kecil maupun besar di bumi ini. Hal ini merupakan karakteristik bumi itu sendiri dalam mempertahankan kestabilannya yang merupakan gejala alamiah. Korban jiwa dan harta yang ditimbulkan juga tidak sedikit jumlahnya jika gempa terjadi dalam skala besar. Pembangunan sistem peringatan dini gempa bumi seharusnya sudah menjadi motifasi para peneliti untuk lebih fokus pada hal tersebut dilihat dari berbagai tempat kejadian gempa bumi di Indonesia seperti gempa bumi Aceh, Medan, Padang, Jogjakarta dan berbagai wilayah lainnya. Pada penelitian : rancang bangun prototipe sitem peringatan dini gempa bumi [1] , kalibrasi dan karakterisari sensor fluxgate magnetometer serta sensor suhu tanah untuk sistem peringatan dini gempa bumi [2][3] telah berhasil dilaksanakan namun perlu adanya metode lain dalam pengiriman data sensor yakni menggunakan metode telemetri secara otomatis berbasis IoT (Internet of Thing) yang sebelumnya menggukan kabel dalam pengiriman datanya. Penggunaan metode 
ini diharapkan nantinya data-data dari sensor menunju ke server dapat menjangkau lebih jauh dan terkirim dengan baik serta tidak terjadi data loss sehingga prediksi peringatan dini gempa bumi lebih akurat. Sistem peringatan dini yang dibangun dapat memperkirakan kapan waktu datangnya, besar kecilnya gempa dan letak gempa. Sensor-sensor yang digunakan antara lain sensor fluxgate magnetometer, sensor suhu tanah dan Receiver FM. Perlu implementasi metode telemetri dalam sistem tersebut untuk menjangkau sensor-sensor letaknya jauh. Gempa bumi dapat diprediksi kapan terjadinya, kekuatannya gempanya dan letak pusat gempanya karena ada beberapa gejala atau fenomena alam yang terjadi beberapa waktu sebelum gempa itu terjadi. Beberapa tanda atau gejala awal akan datangnya gempa bumi adalah fenomena Total Electron Content pada lapisan ionosfer [4][5][6] Akibat pergerakan lempeng, terjadi rekahan yang memengaruhi gaya berat dan mineral magnetis di dalam bumi sehingga mengganggu kestabilan gaya medan elektromagnetik. Gangguan ini bisa sampai radius 400 kilometer di atas permukaan bumi pada lapisan ionosfer dan peningkatan geomagnetism pada permukaan bumi dalam waktu tertentu sebelum terjadinya gempa [7][8] [9] dan geomagnetism dapat dideteksi menggunakan sensor MAG3110 [10] [11] Selain itu juga sensor DHT11 dapat digunakan untuk memonitor gempa melalui perubahan suhu tanah yang terjadi seperti yang telah dilakukan oleh [12].

Sudah tidak dapat dipungkiri lagi bahwasannya korban gempa bumi di seluruh wilayah banyak memakan korban jiwa. Sebagaimana dipaparkan pada data berikut.

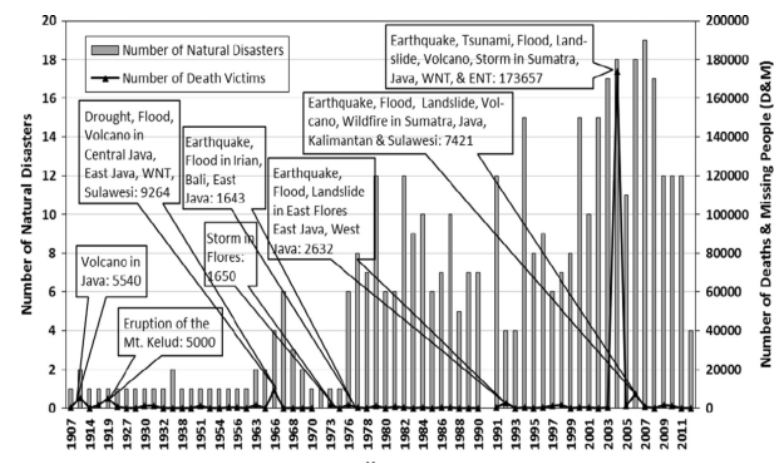

Gambar 1. Statistik gempa bumi dan jumlah korban jiwa 1900 s.d 2012 [13]

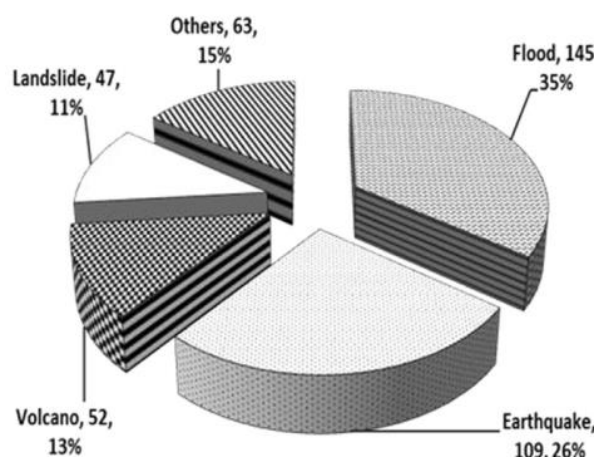

Gambar 2. Statistik jenis bencana alam

Jumlah tertinggi kematian dan hilang dari bencana gempa bumi terjadi pada tahun 2014, tercatat 18 kali bencana alam gempa bumi, dan salah satunya terjadi gempa yang sangat besar yang mengakibatkan tsunami yang mengakibatkan kurang lebih 172.761 korban jiwa. Jika dilihat dari statistik jenis bencana alamnya pun jenis bencana alam gempa bumilah yang sering terjadi sebagaimana dijelaskan pada gambar berikut.

Terakhir yang terjadi di Palu, Sulawesi tengah 28 September 2018 7,8 skala rickter kurang lebih menimbulkan korban jiwa sebanyak 2000 jiwa [14]. BMKG baru memberikan gambaran gempa yang sudah terjadi mengenai tempat, waktu dan kekuatan. BMKG belum mampu memprediksi waktu akan datanya gempa oleh karena itu sudah seharusnya sistem peringatan dini ini 
dibangun untuk mengantisipasi akibat gempa yang ditimbulkan, mengkoordinasi bantuan oleh SAR, lokasi pengungsian dan lain-lain. Dengan mengimplementasikan metoda telemetri berbasis IoT pada sistem tersebut diharapkan dapat menjangkau penempatan sensor yang jauh pada daerahdaerah rawan gempa nantinya dan akhirnya dapat meningkatkan keakuratan prediksi gempa dan banyak menyelamatkan jiwa.

objek $\begin{array}{rcc}\text { Telemetri adalah penggukuran } \\ \text { tertentu dari jarak jauh }\end{array}$
menggunakan komunikasi secara wireless, contohnya adalah telemetri pada smat home oleh [15][16][17] untuk akuisisi data sensor yang diletakan pada rumah. Sensorsensor tersebut digunakan untuk memantau kondisi fisis rumah baik suhu, intensitas cahaya dan kimia. Pada penelitian yang akan dilaksanakan ini akan menerapkan telemetri pada sensor MAG3110 dan ADXL345 untuk memantau kondisi fisis bumi baik kemagnetan dan getaran bumi. Berbicara mengenai telemeri tidak lepas dari otomasi, otomasi adalah teknik yang menggabungkan ilmu elektronika dengan sistem yang berbasis komputer melalui prosedur yang disusun menurut intruksi tertentu sehingga terdapat unpan balik didalamnya untuk mengoreksi apakah instruksi yang diberikan sudah terlaksana dengan baik. Otomasi menekankan efisiensi, produktivitas, kualitas, dan keandalan, dengan fokus pada sistem yang beroperasi secara baik [18].

IoT merupakan sebuah konsep yang memperluas manfaat jaringan internet yang tersambung terus-menerus, dengan adanya konsep ini suatu objek atau device dapat mengirim dan menerima data secara otomatis tanpa banyak campur tangan manusia. Penerapan konsep ini pada akhirnya akan mempermudah aktivitas manusia. Banyak penerapan konsep ini seperti Smart Garbage [19] memonitoring kotak sampah sudah penuh atau belum sehinga proses pengambilan kotak sampah oleh petugas lebih efektif. IoT pada tanaman hidroponik [20] untuk memonitoring $\mathrm{PH}$ air agar tanaman hidroponik dapat tumbuh dengan baik. Integrasi IoT pada e-KTP [21] pemanfaatan IoT untuk membaca ID yang ada pada e-KTP dengan integrasi ini pemanfaatan e-KTP lebih luas tanpa harus membuat kartu identitas yang lain. Integrasi sensor physiologi dengan IoT [22] untuk memonitoring tingkat stres seseorang dalam setiap aktivitasnya seharihari. Integrasi IoT pada robot pendeteksi logam [23] untuk mengurangi resiko radioaktif pada proses pendeteksian logam yang biasa dilakukan manusia secara langsung, dengan memanfaatkan IoT pendeteksian bisa dilakukan secara jarak jauh. Impelementasi IoT pada Smart Parking dengan metode pengenalan wajah serta pengenalan plat kendaraan [24][25]. Integerasi IoT pada kendaraan Taksi [26] untuk memonitoring taksi mengalamai kecelakaan atau tidak. Membangun penghubung antara jaringan sensor dengan IoT menggunakan Internet Gateway Device (IGD) sehingga mengurangi delay rata-rata dalam jaringan sensor tersebut [27][28][29]. Integrasi IoT pada kartu tol [30]. Pembangunan sistem informasi yang memberikan layanan informasi daerah wisata yang sering dikunjungi wisata [31][32]. Pemanfaatan IoT untuk menejemen irigasi [33]. Dari berbagai pemanfaatan IoT yang sudah pernah dilakukan seperti di atas, peneliti akan menerapkan IoT pada sistem peringatan dini gempa bumi. 


\section{METODE PENELITIAN}

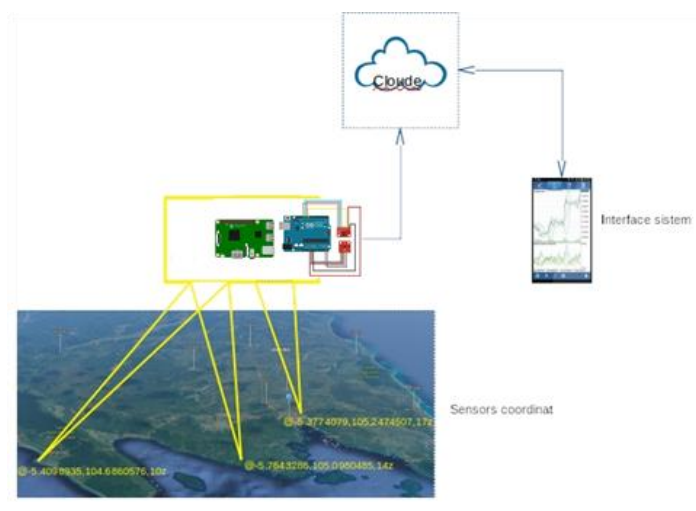

Gambar 3. Letak sensor

Desain telemetri sensor MAG3110 dan ADXL345 ditunjukan pada Gambar 3, dimana dibagi menjadi dua sistem. sistem yang pertamana terdiri dari sensor MAG3110, ADXL345, Modem GSM dan sistem yang kedua interface untuk menampilkan data-data dari sensor.

Sensor MAG3110 dengan supply voltage $1.95 \mathrm{~V}$ to $3.6 \mathrm{~V}$ (VDD), $1.62 \mathrm{~V}$ to VDD IO voltage (VDDIO), ukuran $2 \mathrm{~mm}$ x $2 \mathrm{~mm}$ x $0.85 \mathrm{~mm}, 0.4 \mathrm{~mm}, 10$-pin package, Full-scale range $\pm 1000 \mu \mathrm{T}$, Sensitivity of $0.10 \mu \mathrm{T}$, Noise down to 0.25 $\mu \mathrm{T}$ rms, Output Data Rates (ODR) up to $80 \mathrm{~Hz}, 400 \mathrm{kHz}$ Fast Mode compatible I 2 $\mathrm{C}$ interface, low-power, single-shot measurement mode, RoHS compliant [34]. The ADXL345 is a small, thin, ultralow power, 3-axis accelerometer with high resolution (13-bit) measurement at up to $\pm 16 \mathrm{~g}$. Digital output data is formatted as 16-bit twos complement and is acces- sible through either a SPI (3- or 4-wire) or I2 C digital interface[35]. Sensor MAG3110 dan ADXL345 diletakkan pada koordinat $(-5.640274,104.3050093)$ dan $(-5.600941$, 104.7788183) mikrokontroler dan modem GSMakan mengirim data kemagnetan dan getaran bumi ke interface sistem menggunakan GSM menggunakan celluler network. Sistem interface digunakan untuk menampilkan data-data sensor dalam bentuk grafik satu dimensi. Algoritma flowchart masing-masing sistem pada setiap koordinat sebagai berikut :

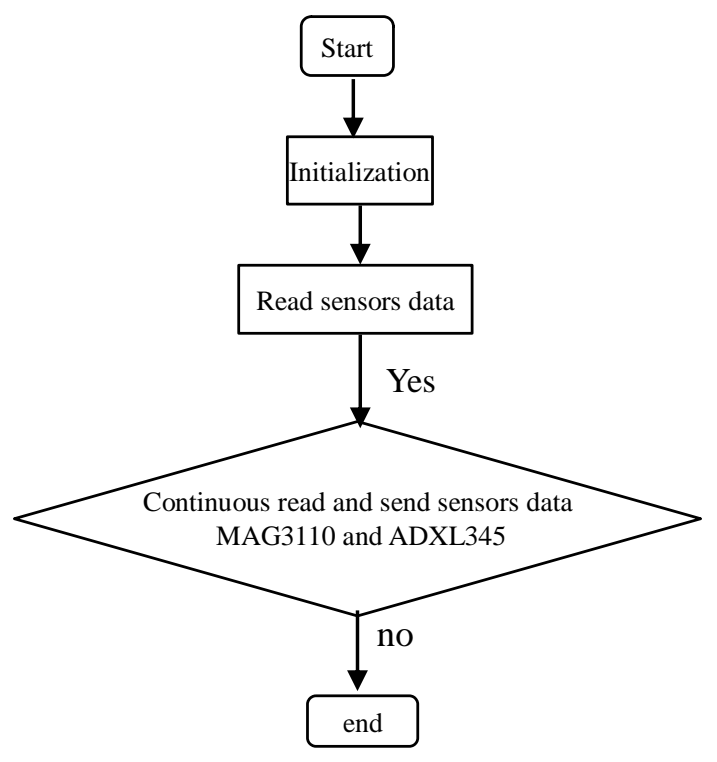

Gambar 4. Flowchart kode program

Sensor MAG3110 dan ADXL345 disusun saling tegak lurus antar koordinat, baik koordinat $\mathrm{x}, \mathrm{y}$ dan $\mathrm{z}$ seperti nampak pada gambar berikut

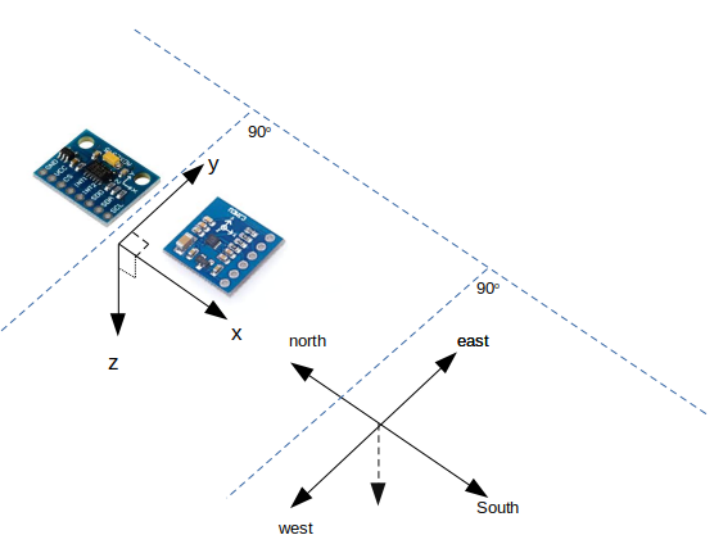

Gambar 5. Susunan sensor 
Sususan sensor seperti diatas untuk menentukan hubungan perubahan nilai fluxmagmet bumi dengan perubahan getaran atau gempa yang terjadi. Koordinat sensor ADXL345 arah sumbu x tegak lurus dengan koordinat sensor MAG3110 arah sumbu y dan tegak lurus dengan arah mata angin bumi. Untuk memperoleh gerakan tiga dimensi, sensor ADXL345 diletakan pada kantilever dengan bahan baja yang memiliki modulus young sebesar 19.9 Gpa. Panjang kantilever $\mathrm{L}=10 \mathrm{~cm}$. Modulus young mendefinisikan huhungan antara tegangan $(\sigma)$ dengan regangan $(e)$

$$
\mathrm{Y}=\frac{\sigma}{e}
$$

dimana tegangan didefinisikan sebagai gaya persatuan luas

$$
\sigma=\frac{F}{A}
$$

dalam satuan internasional $\mathrm{F}$ : gaya $(\mathrm{N})$, A : luas $\left(\mathrm{m}^{2}\right)$ sehingga $\sigma$ : tegangan $\left(\mathrm{N} / \mathrm{m}^{2}\right)$. Sedangkan regangan adalah pertambahan panjang $(\Delta \mathrm{L})$ dari panjang mula-mula (L).

$$
\mathrm{e}=\frac{\Delta \mathrm{L}}{L}
$$

dimana $\Delta \mathrm{L}$ : pertambahan panjang $(\mathrm{m})$ dan L : Panjang mula-mula (m). Dengan demikian kita modulus young dinyatanyakan dengan

$$
\mathrm{Y}=\frac{\mathrm{FxL}}{\mathrm{Ax} \Delta \mathrm{L}}
$$

dimana $\mathrm{Y}$ : modulus young $\left(\mathrm{N} / \mathrm{m}^{2}\right)$. Dengan nilai $\mathrm{F}=0.0018 \mathrm{~N}, \mathrm{~L}=0.1 \mathrm{~m}, \Delta \mathrm{L}$ $=0.01 \mathrm{~m}$ dan $\mathrm{A}=0.0001 \mathrm{~m}^{2}$ nilai modulus young sebesar 19,9 Gpa.

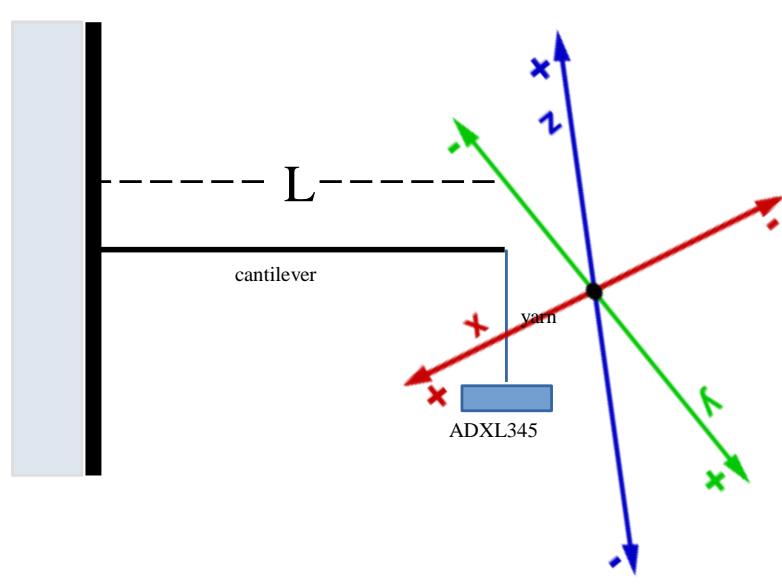

Gambar 6 Kantilever sensor

Rangkaian secara keseluruhan masing-masing sistem sensor seperti nampak pada gambar sebagai berikut
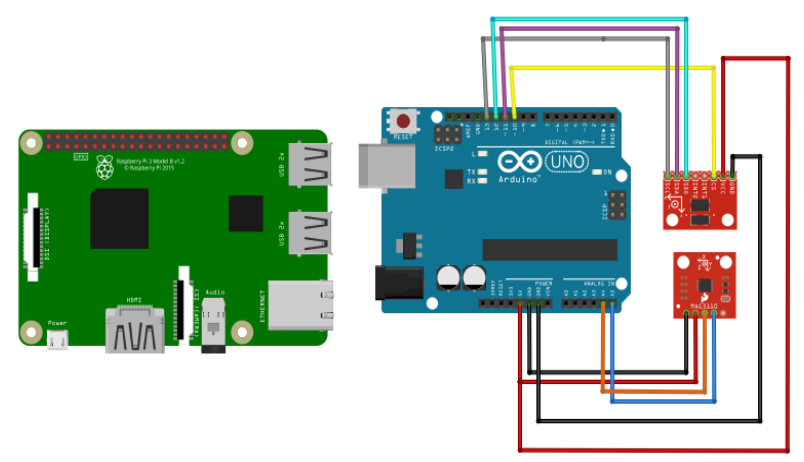

Gambar 7. Rangkain sistem sensor

Komunikasi antara sensor ADXL345 dengan arduino terdiri dari dua yakni komunikasi secara I2C (Inter Integrated Circuit) dan SPI (Serial Peripheral interface). Dalam board arduino terdapat mikrokontroler ATmega328P, with 8-bit AVR Microcontroller with 32K Bytes In-System Programmable Flash. Have RISC architecture and Up to 16MIPS throughput at $16 \mathrm{MHz}$ in On-chip 2-cycle multiplier [36].Pada rangkain diatas komunikasi antara arduino dengan sensor menggunakan SPI. Komunikasi 
data ini memiliki beberapa keuntungan dibanding dengan komonikasi data secara I2C. Kecepatan transfer data lebih cepat dan dapat melakukan pengiriman dan penerimaan data secara bersamaan serta tidak diperlukan penambahan resistor pullup. Komunikasi data secara SPI ini diperlukan untuk memperoleh tingkat kesensitifan sensor. Begitu juga dengan sensor MAG3110, penyensoran kemagnetan bumi secara tiga dimensi dilakukan bersamaan dengan sensor ADXL345. Kedua data tersebut melului arduino dikirimkan ke cloud menggunakan Raspberry pi3. Raspberry Pi 3 memiliki Mikroprosesor $1.2 \mathrm{GHz}$ 64-bit quad-core ARMv8 CPU - 802.11n dan memiliki Wireless LAN - Bluetooth 4.0 Bluetooth Low Energy (BLE) [37]. Pada arduino tambahkan library BlynkSimpleStrem. Untuk memfungsikan rasbrry pi 3 sebagai server diperlukan perangkat lunak Node.js, langkah-langkah untuk men-setting Node.js raspberry pi3 yakni dengan menambahkan repositories peng-install-an rasberry untuk Node.js dengan kode curl sL https://deb.nodesource.com/setup_12.x | sudo -E bash - menggunakan terminal rasberry pi3 melakukan peng install an dengan kode sudo apt-get install buildessential nodejs - dan lengkapi dengan library Blynk dengan kode sudo npm install blynk-library -g. Pada direktor library Blynk, running Blynk-ser.sh.

Data getaran dari sensor ADXL345 dan data flux magnet dari sensor MAG3110 merupakan besaran vektor. Untuk memudahkan tampilan grafik data dapat ditentukan resultan dari ketiga vektor tersebut dengan rumus sebagai berikut :

$$
\vec{R}=\sqrt{\overrightarrow{x^{2}}+\overrightarrow{y^{2}}+\overrightarrow{z^{2}}}
$$

\section{HASIL DAN PEMBAHASAN}

Setelah dilakukan proses pengukuran didapat grafik data getaran dan kemagnetan bumi pada tiga koordinat bumi seperti Gambar 8.

Seperti nampak pada gambar, terdapat keterkaitan antara perubahan atau anomali resultan fluxmagnet bumi dengan resultan simpangan getaran yang terjadi pada sensor ADXL345. Rata rata impact yang ditimbulkan 400 detik atau 6,6 menit dari anomali resultan fluxmagnet. Anomali data flux magnet dengan rentang $395 \mu \mathrm{T}$ sampai dengan $404 \mu \mathrm{T}$ mengakibatkan resultan simpangan $1 \mathrm{~mm}$ pada kantilever sensor ADXL345. Hal ini dapat dijadikan dasar untuk membangun sistem peringatan dini gempa bumi secara real time.

\section{KESIMPULAN}

Setelah dilakukan pengukuran fulxmagnet dan getaran bumi menggunakan metode telemetri berbasis IoT didapat kesimpulan bahwa terdapat keterkaitan antara anomali fluxmagnet dengan getaran bumi. Rata-rata impact yang ditumbulkan dari timbulnya anomali dengan datangnya getaran pada koordinat yang sama membutuhkan waktu 400 detik dari rentang anomali sebesar $395 \mu \mathrm{T}$ sampai dengan $404 \mu \mathrm{T}$. Hal ini menurut peneliti dapat dijadikan hitotesis untuk membangun sistem peringatan gempa bumi secara real time. 

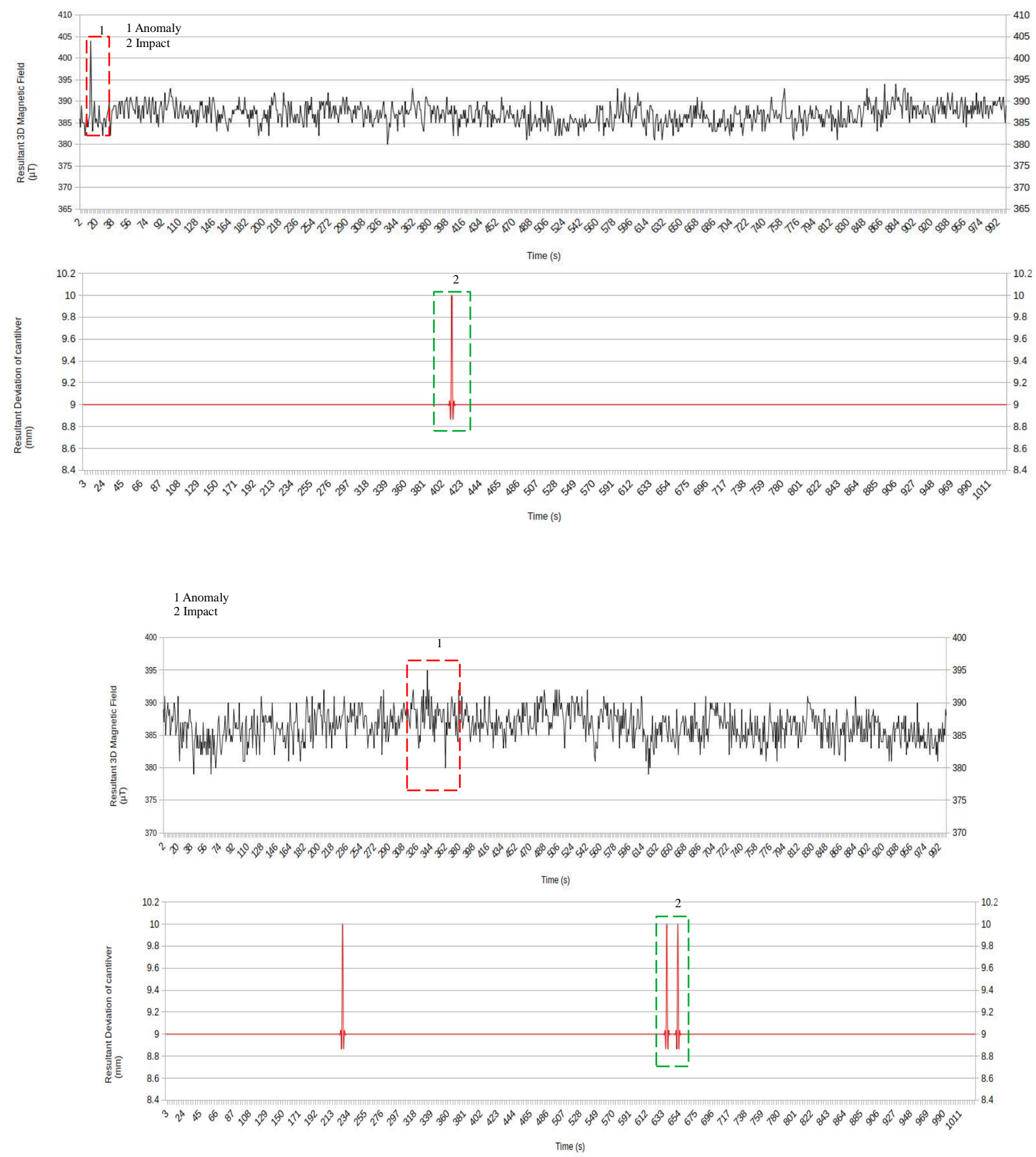

Gambar 8 Grafik data output sensor 


\section{DAFTAR PUSTAKA}

[1] D. Y. Setyawan and N. Zaidal, "Earthquake Early Warning System Real Time Design Using Total Electron Content and Geomagnetism with Fuzzy Logic," Int. J. Comput. Sci. Issues, vol. 11, no. 6, pp. 38-44, 2014, [Online]. Available:

https://search.proquest.com/docvie w/1640566416? accountid $=8144 \% 0$ Ahttp://sfx.aub.aau.dk/sfxaub?url_v er $=$ Z39.88-

2004\&rft_val_fmt=info:ofi/fmt:kev: $\mathrm{mtx}$ :journal\&genre=article \&sid=Pro Q:ProQ\%3Amaterialscienceenginee ring\&atitle $=$ Earthquake + Early + War ning+System+Real+.

[2] D. Y. Setyawan, D. Yuliawati, Warsito, and Warsono, "Calibration of geomagnetic and soil temperatur sensor for earthquake early warning system," Telkomnika (Telecommunication Comput. Electron. Control., 2018, doi: 10.12928/TELKOMNIKA.v16i5.75 92.

[3] S. D.Y, Y. D, W. Warsito, and W. Warsono, "Determination Model of Tectonic Seismicity Level In Earthquake Early Warning System By Implementing ANFIS (Adaptive Neuro Fuzzy Inference Systems)," pp. 283-291, 2019, doi: 10.4108/eai.24-10-2018.2280617.

[4] [J. A. Strauss and R. M. Allen, "Benefits and costs of earthquake early warning," Seismol. Res. Lett., vol. 87 , no. 3 , pp. 765-772, 2016, doi: $10.1785 / 0220150149$.

[5] Remote Sensing of Northwest Himalayan Ecosystems. Springer Singapore, 2019.

[6] X. Lin, Y. C. Su, T. J. Y. Liu, and J. Sha, "Temporal and Spatial Correlation Analyses between Precursory Ionospheric Parameters and Earthquake Energy by Using Total Electron Content of Global Ionosphere Maps," in AGU Fall Meeting Abstracts, 2018, vol. 2018, pp. NH13D-0718.

[7] K. Hattori, P. Han, and J. Zhuang, "Assessment of ULF geomagnetic precursor for short-term earthquake forecast," in EGU General Assembly Conference Abstracts, Apr. 2018, p. 17007.

[8] Y. Zhu, "Hypothesis on the Cycle of Japan M=7.8 earthquake," in International Geophysical Conference, Beijing, China, 24-27 April 2018, 2018, pp. 710-716.

[9] Z. Li, J. An, H. Yin, Y. Tian, and W. Yu, "Study on Association Rules Between Earthquake Event and Earthquake Precursory Information Anomalies," in 2018 11th International Congress on Image and Signal Processing, BioMedical Engineering and Informatics (CISP-BMEI), 2018, pp. 1-6, doi: 10.1109/CISPBMEI.2018.8633171. 
[10] Chen, Xiaoyu and Orense, Rolando P., "Development of a magnetic tracking system for monitoring soil movements induced by geohazards," E3S Web Conf., vol. 92, p. 17007, 2019, doi: 10.1051/e3sconf/20199217007.

[11] A. Lackey and A. Lackey, "Detecting Geomagnetically Induced Currents in Electric Power Transmission Lines by,” 2018.

[12] R. C. Abayon et al., "A Weather Prediction and Earthquake Monitoring System," in 2018 IEEE Conference on Systems, Process and Control (ICSPC), 2018, pp. 203-208, doi: 10.1109/SPC.2018.8704138.

[13] N. B. Parwanto and T. Oyama, "A statistical analysis and comparison of historical earthquake and tsunami disasters in Japan and Indonesia," Int. J. Disaster Risk Reduct., 2014, doi: 10.1016/j.ijdrr.2013.10.003.

[14] I. S. Wekke, Z. Sabara, M. A. Samad, A. Yani, R. Umam, and M. U. Palu, "Earthquake, Tsunami, and Society Cooperation: Early Findings in Palu Post of Indonesia Disaster," Int. Conf. Challenges Oppor. Sustain. Environ. Dev., 2019.

[15] T. A. Abdulrahman, O. H. Isiwekpeni, N. T. SurajudeenBakinde, and A. O. Otuoze, "Design, Specification and Implementation of a Distributed Home Automation System," Procedia Comput. Sci., vol. 94, no.
IoTNAT, pp. 473-478, 2016, doi: 10.1016/j.procs.2016.08.073.

[16] A. Ahmim, T. Le, E. Ososanya, and S. Haghani, "Design and implementation of a home automation system for smart grid applications," 2016 IEEE Int. Conf. Consum. Electron. ICCE 2016, pp. 538-539, 2016, doi: 10.1109/ICCE.2016.7430721.

[17] R. K. Kodali and S. R. Soratkal, "MQTT based home automation system using ESP8266," IEEE Reg. 10 Humanit. Technol. Conf. 2016, R10-HTC 2016 - Proc., no. December 2016, 2017, doi: 10.1109/R10-HTC.2016.7906845.

[18] B. Kehoe, S. Patil, P. Abbeel, and K. Goldberg, "A Survey of Research on Cloud Robotics and Automation," IEEE Trans. Autom. Sci. Eng., 2015, doi: 10.1109/TASE.2014.2376492.

[19] [ R. H. Putra, F. T. Kusuma, T. N. Damayanti, and D. N. Ramadan, "IoT: smart garbage monitoring using android and real time database," vol. 17 , no. 3 , pp. $1483-$ 1491, 2019, doi: 10.12928/TELKOMNIKA.v17i3.10 121.

[20] R. B. Lukito and C. Lukito, "Development of IoT at hydroponic system using raspberry $\mathrm{Pi}$," Telkomnika (Telecommunication Comput. Electron. Control., 2018, doi: 
10.12928/TELKOMNIKA.V17I2.9 265.

[21] R. M. Awangga, N. H. Harani, and M. Y. H. Setyawan, "KAFA: A novel interoperability open framework to utilize Indonesian electronic identity card," Telkomnika (Telecommunication Comput. Electron. Control., vol. 17, no. 2, pp. 712-718, 2019, doi: 10.12928/TELKOMNIKA.V17I2.1 1755.

[22] K. Sethi, T. Ramya, H. P. Singh, and R. Dutta, "Stress detection and relief using wearable physiological sensors," Telkomnika (Telecommunication Comput. Electron. Control., vol. 17, no. 3, pp. 1139-1146, 2019, doi: 10.12928/TELKOMNIKA.V17I3.9 719.

[23] N. S. Ali, H. A. Kadhim, and D. M. Abdulsahib, "Multi-function intelligent robotic in metals detection applications," TELKOMNIKA

(Telecommunication Comput. Electron. Control., vol. 17, no. 4, p. 2058, 2019, doi: 10.12928/telkomnika.v17i4.11822.

[24] R. P. Persada, S. Aulia, B. D., and S. H., "Automatic face and VLP's recognition for smart parking system," TELKOMNIKA (Telecommunication Comput. Electron. Control., 2019, doi: 10.12928/telkomnika.v17i4.11746.
[25] D. N. C. Loong, S. Isaak, and Y. Yusof, "Machine vision based smart parking system using Internet of Things," TELKOMNIKA (Telecommunication Comput. Electron. Control., vol. 17, no. 4, p. 2098, 2019, doi: 10.12928/telkomnika.v17i4.12772.

[26] I. Indrianto, M. N. I. Susanti, R. R. A. Siregar, J. P. Putri, and Y. Purwanto, "Smart taxi security system design with Internet of Things (IoT)," Telkomnika (Telecommunication Comput. Electron. Control., vol. 17, no. 3, pp. 1250-1255, 2019, doi: 10.12928/TELKOMNIKA.V17I3.1 0167.

[27] E. S. Pramukantoro, M. Luckies, and F. A. Bakhtiar, "Bridging IoT infrastructure and cloud application using cellular-based internet gateway device," Telkomnika (Telecommunication Comput. Electron. Control., vol. 17, no. 3, pp. 1439-1446, 2019, doi: 10.12928/TELKOMNIKA.V17I3.1 2229.

[28] A. Karim Mohamed Ibrahim, R. A. Rashid, A. H. F. A. Hamid, M. Adib Sarijari, and M. A. Baharudin, "Lightweight IoT middleware for rapid application development," Telkomnika (Telecommunication Comput. Electron. Control., vol. 17, no. 3, pp. 1385-1392, 2019, doi: 10.12928/TELKOMNIKA.V17I3.1 1793. 
[29] A. Bhawiyuga, D. P. Kartikasari, K. Amron, O. B. Pratama, and M. W. Habibi, "Architectural design of IoT-cloud computing integration platform," Telkomnika (Telecommunication Comput. Electron. Control., 2019, doi: 10.12928/TELKOMNIKA.V17I3.1 1786.

[30] S. A. W. Al-abassi, K. Y. A. Albayati, M. R. R. Sharba, and L. Abogneem, "Smart prepaid traffic fines system using RFID, IoT and mobile app," TELKOMNIKA (Telecommunication Comput. Electron. Control., vol. 17, no. 4, p. 1828, 2019, doi: 10.12928/telkomnika.v17i4.10771.

[31] R. Amjed and M. S. Croock, "Dominated destinations of tourist inside Iraq using personal information and frequency of travel," TELKOMNIKA (Telecommunication Comput. Electron. Control., vol. 17, no. 4, p. 1723, 2019, doi: 10.12928/telkomnika.v17i4.11956.

[32] N. Nguyen, Q. C. Nguyen, and M. T. Le, "A novel autonomous wireless sensor node for IoT applications," TELKOMNIKA
(Telecommunication

Comput.

Electron. Control., 2019, doi: 10.12928/telkomnika.v17i5.12811.

[33] S. R. Sulistiyanti, F. X. A. Setyawan, and M. Komarudin, "Detection air pollution based on infrared image processing," TELKOMNIKA

(Telecommunication

Comput.

Electron. Control., 2019, doi: 10.12928/telkomnika.v17i4.12824.

[34] Freescale Semiconductor, "Freescale Semiconductor Xtrinsic MAG3110 Three-Axis, Digital Magnetometer," MAG3110 datasheet, no. 9.2, pp. 1-30, 2013, [Online]. Available: http://cache.freescale.com/files/sens ors/doc/data_sheet/MAG3110.pdf.

[35] Analog Devices, "Digital Accelorometer Data Sheet," p. 40, 2009.

[36] A. V. R. Microcontroller, “ATmega328P," pp. 1-294.

[37] Raspberry Pi Foundation, "Raspberry Pi 3 Model B+ Datasheet," Datasheet, p. 5, 2016, [Online]. Available: https://static.raspberrypi.org/files/prod uct-briefs/Raspberry-Pi-Model-BplusProduct-Brief.pdf. 
Dodi Yudo Setyawan, dkk: Gempa Bumi : Hubungan data sensor MAG3110 dengan data sensor ADXL345 berbasis IoT 